\title{
Pengembangan dan Penyusunan Bahan Ajar Mata Kuliah Pendidikan Kewargaan Negara sesuai Kebutuhan Mahasiswa dan Masyarakat pada Program PGSD FKIP Unib
}

\author{
Osa Juarsa \\ PGSD FKIP Unib \\ Puspa Djuwita \\ PGSD FKIP Unib
}

\begin{abstract}
Agar kompetensi lulusan serta isi bahan ajar sesuai dengan tuntutan KKNI serta tuntutan kebutuhan lapangan (stakeholder) maka isi kompetensi lulusan serta semua bahan ajar perlu ditinjau ulang untuk disesuaikan dengan jenjag kompetensi KKNI dan kebutuhan stakeholder. Jenis penelitian ini termasuk penelitian survey yaitu peneliti berupaya untuk mengumpulkan informasi tentang kompetensi lulusan dan bahan ajar dari stakeholder dan mahasiswa yang diharapkan dimiliki oleh mahasiswa PGSD setelah menempuh mata kuliah Pendidikan Kewarganegaraan. Data dikumpulkan melalui angket yang disusun berdasarkan pokok-pokok bahan ajar yang selayaknya dikuasai oleh mahasiswa PGSD, disamping kemungkinan baru tambahan kompetensi dan isi kompetensi menurut responden. Data yang terkumpul dianalis secara deskriptif argumentatif mengenai isi kompetensi dan bahan ajar yang seharusnya dikuasai oleh mahasiswa. Kesimpulan menunjukan bahwa kompetensi dan pokok-pokok bahan ajar Mk PKn yang sesuai dengan kebutuhan mahasiswa dan stakeholder yaitu konsep dasar hakikat pendidikan kewarganegaraan, esensi dan urgensi identitas nasional, urgensi integrasi nasional, nilai dan norma UUD NRI 1945 dan konstitusionalitas, harmoni kewajiban dan hak Negara dan warga Negara dalam demokrasi, Dinamika historis konstitusional social politik, kultural serta konteks kontemporer penegakkan hokum yang berkeadilan, Wawasan Nusantara, dan Ketahanan Nasional
\end{abstract}

Kata kunci : Pkn, Bahan ajar, Mahasiswa, Stakeholder 


\section{Pendahuluan}

Secara historis, PKn di Indonesia senantiasa mengalami perubahan baik istilah maupun substansi sesuai dengan perkembangan peraturan perundangan, iptek, perubahan masyarakat, dan tantangan global. Secara sosiologis, PKn Indonesia sudah sewajarnya mengalami perubahan mengikuti perubahan yang terjadi di masyarakat. Secara politis, PKn Indonesia akan terus mengalami perubahan sejalan dengan perubahan sistem ketatanegaraan dan pemerintahan, terutama perubahan konstitusi.

Belajar tentang Pendidikan Kewarganegaraan (PKn) pada dasarnya adalah belajar tentang keindonesiaan, belajar untuk menjadi manusia yang berkepribadian Indonesia, membangun rasa kebangsaan, dan mencintai tanah air Indonesia. Oleh karena itu, seorang sarjana atau profesional sebagai bagian dari stakeholder Indonesia yang terdidik perlu memahami tentang Indonesia, memiliki kepribadian Indonesia, memiliki rasa kebangsaan Indonesia, dan mencintai tanah air Indonesia. Dengan demikian, ia menjadi warga negara yang baik dan terdidik (smart and good citizen) dalam kehidupan stakeholder, bangsa, dan negara yang demokratis. Secara historis, PKn di Indonesia senantiasa mengalami perubahan baik istilah maupun substansi sesuai dengan perkembangan peraturan perundangan, iptek, perubahan stakeholder, dan tantangan global. Secara sosiologis, PKn Indonesia sudah sewajarnya mengalami perubahan mengikuti perubahan yang terjadi di stakeholder. Secara politis, PKn Indonesia akan terus mengalami perubahan sejalan dengan perubahan sistem ketatanegaraan dan pemerintahan, terutama perubahan konstitusi.

Dalam merespon perkembangan Iptek dan globalisasi pada tahun 2012 Indonesia telah mengembangkan Kurikulum Perguruan Tinggi yang disebut Kualifikasi Krikulum Nasional Indonesia (KKNI) (Peraturan Presiden RI Nomor 8 Tahun 2012). KKNI, adalah kerangka penjenjangan kualifikasi kompetensi yang dapat menyandingkan, menyetarakan, dan mengintegrasikan antara bidang pendidikan dan bidang pelatihan kerja serta pengalaman kerja dalam rangka pemberian pengakuan kompetensi kerja sesuai dengan struktur pekerjaan di bidangnya. Undang-Undang RI No. 20 Tahun 2003 tentang Sisdiknas Pasal 37 Ayat (1) huruf b yang menyatakan bahwa kurikulum pendidikan dasar dan menengah wajib memuat pendidikan kewarganegaraan. Demikian pula pada ayat (2) huruf b dinyatakan bahwa kurikulum pendidikan tinggi wajib memuat pendidikan kewarganegaraan. Bahkan dalam UU No. 12 Tahun 2012 tentang Pendidikan Tinggi lebih eksplisit dan tegas dengan menyatakan nama mata kuliah kewarganegaraan sebagai mata kuliah wajib. Dikatakan bahwa mata kuliah kewarganegaraan adalah pendidikan yang mencakup Pancasila, Undang- Undang Dasar Negara Republik Indonesia Tahun 1945, Negara Kesatuan Republik Indonesia dan Bhinneka Tunggal Ika untuk membentuk mahasiswa menjadi warga negara yang memiliki rasa kebangsaan dan cinta tanah air. Mata Kuliah Wajib Umum (MKWU) pada Perguruan Tinggi memiliki posisi strategis dalam melakukan transmisi pengetahuan dan transformasi sikap serta perilaku mahasiswa Indonesia melalui proses pembelajaran. Dalam upaya meningkatkan mutu lulusan dan pembentukan karakter bangsa perlu dilakukan peningkatan dan perbaikan materi yang dinamis mengikuti perkembangan yang senantiasa dilakukan secara terus menerus, dan dimutakhirkan sesuai dengan dinamika kebutuhan dan perubahan zaman, serta semangat belanegara.

Dalam Undang-Undang Republik Indonesia Nomor 12 Tahun 2012 tentang Pendidikan Tinggi, program sarjana merupakan jenjang pendidikan akademik bagi lulusan pendidikan menengah atau sederajat sehingga mampu mengamalkan ilmu pengetahuan dan teknologi melalui penalaran ilmiah. Lulusan program 
sarjana diharapkan akan menjadi intelektual dan/atau ilmuwan yang berbudaya, mampu memasuki dan/atau menciptakan lapangan kerja, serta mampu mengembangkan diri menjadi profesional. Dalam Undang-Undang Republik Indonesia Nomor 14 Tahun 2005 tentang Guru dan Dosen dikemukakan bahwa profesional adalah pekerjaan atau kegiatan yang dapat menjadi sumber penghasilan, perlu keahlian, kemahiran, atau kecakapan, memiliki standar mutu, ada norma dan diperoleh melalui pendidikan profesi.

Penerapan Kurikulum Pendidikan Tinggi (KPT) sesuai Standar Nasonal Pendidikan Tinggi dan mengacu kerangka Kualifikasi Nasional Indonesia (KKNI), ditindaklanjuti dengan penulisan buku ajar yang dapat dijadikan sumber aktivitas pembelajaran MKWU dalam rangka mendidik lulusan yang berkarakter Bangsa Indonesia. Pembelajaran disajikan dengan pendekatan aktivitas berpusat pada mahasiswa ( student centered learning / SCL). Pembelajaran yang diselenggarakan merupakan proses yang mendidik melalui proses berpikir kritis, analitis, induktif, deduktif, reflektif serta memicu "high order thinking" melalui dialog kreatif partisipatori untuk mencapai pemahaman tentang kebenaran substansi dasar kajian, berkarya nyata dan menumbuhkan motivasi belajar sepanjang hayat sejalan dengan konsep General Education.

Agar Kompetensi dan isi kompetensi lulusan serta isi bahan ajar sesuai dengan tuntutan Kerangka Kualfikasi Nasional Indonesia dan sesuai dengan tuntan kebutuhan lapangan (stakeholder) maka Kompetensi lulusan dan isi kompetensi lulusan serta semua bahan ajar PGSD (termasuk kompetensi dan isi bahan ajar mata kuliah "Pendidikan Kewarganegaraan) perlu ditinjau ulang untuk disesuaikan dengan kompetensi, jenjag kompetensi KKNI dan kebutuhan masy. Permasalahannya, pokok pokok dan isi bahan ajar mata kuliah "Pendidikan Kewarganegaraan" yang seperti apakah yang sesuai dengan KKNI dan kebutuan stakeholder? Oleh karena itu tujuan yang mau dicapai dari pembahasan ini adalah terumuskan pokok pokok dan isi bahan ajar yang seharusnya dikuasai oleh mahasiswa PGSD, setelah menempuh mata kuliah Pendidikan Kewarganegaraan.

\section{Metode}

Jenis penelitian ini termasuk penelitian survei yaitu penelitian yang berupaya untuk mengumpulkan informasi tentang kebutuhan kompetensi lulusan dan isi kompetensi dari stakeholder dan mahasiswa yang diharapkan dimiliki oleh mahasiswa PGSD setelah menempuh mata kuliah Pendidikan Kewarganegaraan. Oleh karena itu yang menjadi responden adalah semua mahasiswa PGSD yang telah menempuh dan lulus mata kuliah Pendidikan Kewarganegaraan serta stakeholder (para praktisi Pendidikan di Kota Bengkulu) yaitu guru, kepala sekolah, birokrat di bidang pendidikan.

Data dikumpulkan melalui metode angket. Angket disusun berdasarkan pokokpokok kompetensi yang selayaknya dimiliki dan materi/isi yang harus dikuasai oleh mahasiswa PGSD, disamping kemungkinan baru tambahan kompetensi dan isi kompetensi menurut responden. Pada angket tersebut responden diminta untuk memeilih kompetensi dan sub kompetensi serta isi/materi yang seharusnya dipelajari. Di samping itu rersponden diminta untuk menambahkan kompetensi dan sub komptensi serta isi kompetensi yang menurut respinden dipandang perlu dimasukan dalam pengembangan kompetensi dan bahan ajar bagi seorang mahasiswa PGSD dalam menempuh mata kuliah Pendidikan Kewarganegaraan.

Berdasarkan data yang terkumpul dianalis secara deskriptif argumentatif mengenai pokok pokok dan isi bahan ajar yang seharusnya dikuasai oleh mahasiswa untuk dijadikan bahan menyusun bahan ajar mata kuliah kewarganegaraan pada program 
PGSD. Bahan ajar yang sudah disusun selanjutnya divalidasi kepada pakar yaitu Prof. Dr. Rambar Nur Sasongko untuk diperiksa kelayakannya.

\section{Hasil dan Pembahasan}

Berdasarkan hasil penelitian, responden berpendapat bahwa kemampuan yang seharusnya dimiliki oleh seorang mahasiswa PGSD setelah menempuh mata kuliah PKn yaitu dapat memahami hakikat pendidikan kewarganegaraan dalam mengembangkan kemampuan utuh sarjana ,memahami esensi dan urgensi identitas nasional sebagai salah satu determinan pembangunan bangsa dan karakter, memahami urgensi integrasi nasional sebagai salah satu parameter persatuan dan kesatuan bangsa, memahami nilai dan norma konstitusional UUD NRI 1945 dan konstitusionalitas perundang-undangan di bawah UUD, memahami harmoni kewajiban dan hak negara dan warga negara dalam demokrasi yang bersumbu pada kedaulatan rakyat dan musyawarah untuk mufakat, memahami hakikat, instrumentasi, dan praksis demokrasi indonesia berlandaskan pancasila dan UUD NRI 1945, menjelaskan dinamika historis konstitusional, sosial-politik, kultural, serta konteks kontemporer penegakan hukum yang berkeadilan, menjelaskan dinamika historis, dan urgensi wawasan nusantara sebagai konsepsi dan pandangan kolektif kebangsaan indonesia dalam konteks pergaulan dunia, memahami urgensi dan tantangan ketahanan nasional dan bela negara bagi indonesia dalam membangun komitmen kolektif kebangsaan.

Sehubungan dengan kompetensi tersebut di atas maka pokok-pokok dan isi bahan pembelajaran yang dapat dijadikan rujukan dalam penyusunan bahan ajar yaitu:.

1. Hakikat Pendidikan Kewarganegaraan dalam mengembangkan kemampuan utuh sarjana, mencakup konsep dan urgensi pendidikan kewarganegaraan dalam pencerdasan kehidupan bangsa, diperlukannya pendidikan kewarganegaraan, sumber historis, sosiologis, dan politik tentang pendidikan kewarganegaraan di indonesia, dinamika dan tantangan pendidikan kewarganegaraan, esensi dan urgensi pendidikan kewarganegaraan untuk masa depan

2. Esensi dan urgensi identitas nasional sebagai salah satu determinan pembangunan bangsa dan karakter mencakup materi konsep dan urgensi identitas nasional, diperlukannya identitas nasional, sumber historis, sosiologis, politik tentang identitas nasional indonesia

3. Urgensi integrasi nasional sebagai salah satu parameter persatuan dan kesatuan bangsa, mencakup materi ,konsep dan urgensi integrasi nasional, diperlukannya integrasi nasional, sumber historis, sosiologis, politik tentang integrasi nasional, dinamika dan tantangan integrasi nasional

4. Nilai dan norma konstitusional UUD NRI 1945 dan konstitusionalitas ketentuan perundang-undangan di bawah UUD mencakup materi konsep dan urgensi konstitusi dalam kehidupan berbangsa- negara, perlunya konstitusi dalam kehidupan berbangsa-negara indonesia, sumber historis, sosiologis, dan politik tentang konstitusi dalam kehidupan berbangsa-negara indonesia, dinamika dan tantangan konstitusi dalam kehidupan berbangsa -negara indonesia, esensi dan urgensi konstitusi dalam kehidupan berbangsanegara

5. Harmoni kewajiban dan hak negara dan warga negara dalam demokrasi yang bersumbu pada kedaulatan rakyat dan musyawarah untuk mufakat, mencakup materi konsep dan urgensi harmoni kewajiban dan hak negara dan warga negara, diperlukan harmoni kewajiban dan hak negara dan warga negara indonesia, sumber historis, sosiologis, politik tentang harmoni 
kewajiban dan hak negara dan warga negara indonesia, dinamika dan tantangan harmoni kewajiban dan hak negara dan warga negara

6. Hakikat, instrumentasi, dan praksis demokrasi indonesia berlandaskan Pancasila dan UUD NRI 1945, mencakup materi konsep dan urgensi demokrasi yang bersumber dari Pancasila, diperlukannya demokrasi yang bersumber dari Pancasila, sumber historis, sosiologis, dan politik tentang demokrasi yang bersumber dari Pancasila, dinamika dan tantangan demokrasi yang bersumber dari Pancasila

7. Dinamika historis konstitusional, sosial-politik, kultural, serta konteks kontemporer penegakan hukum yang berkeadilan, mencakup materi, konsep dan urgensi penegakan hukum yang berkeadilan, diperlukannya penegakan hukum yang berkeadilan, sumber historis, sosiologis, politis tentang penegakan hukum yang berkeadilan di Indonesia, dinamika dan tantangan penegakan hukum yang berkeadilan indonesia, esensi dan urgensi penegakan hukum yang berkeadilan Indonesia

8. Dinamika historis, dan urgensi Wawasan Nusantara sebagai konsepsi dan pandangan kolektif kebangsaan Indonesia dalam konteks pergaulan dunia, mencakup materi konsep dan urgensi Wawawan Nusantara, diperlukannya Wawawan Nusantara, sumber historis, sosiologis, dan politik tentang Wawasan Nusantara, dinamika dan tantangan Wawasan Nusantara, esensi dan urgensi Wawasan Nusantara

9. Ketahanan nasional dan bela negara bagi indonesia dalam membangun komitmen kolektif kebangsaan, mencakup materi, konsep dan urgensi ketahanan nasional dan bela negara, diperlukannya ketahanan nasional dan bela negara, sumber historis, sosiologis, politik tentang ketahanan nasional dan bela negara, dinamika dan tantangan ketahanan nasional dan bela negara, esensi dan urgensi ketahanan nasional dan bela negara

10. Menyelenggarakan project citizen untuk mata kuliah Pendidikan Kewarganegaraan meliputi langkah langkah, mengidentifikasi masalah, diskusi kelas: berbagi informasi tentang masalah yang ditemukan dalam stakeholder, memilih masalah untuk bahan kajian kelas, mengumpulkan informasi, mengidentifikasi sumber-sumber informasi, mengembangkan portofolio kelas, menyajikan portofolio dan merefleksi pengalaman belajar

Setelah tersusunnya materi pengembangan bahan ajar PKn untuk mahasiswa diperguruan tinggi, selanjutnya divalidasi ke pakar yaitu Prof. Dr. Rambat Nur Sasongko (Lihat lampiran 4). Aspek yang divalidasi mencakup 1) Keakuratan materi, 2) Kemutakhiran materi 3) Menorong keingintahuan 4) Teknik penyajian 5) Lugas 6) Komunikatif 7) Kesesuaian dengan perkembangan materi 8) Kesesuaian dengan kaidah bahasa 9) Sampul bahasa 10) Topografi isi modul sederhana. Hasil validasi pakar menunjukkan nilai skor rata rata 4,7 dari skor 5 yang tertinggi yang berarti mencapai kategori sangat baik. Beberapa catatan yang diberikan oleh validator terkait bahan ajar PKn yaitu 1) Buku ini sangat baik untuk mahasiswa PGSD dalam memberikan penguatan kompetensi kepribadian tentang pendidikan Kewarganegaraan 2) Harap segera diurus ISBN dan cetak sesuai dengan kaidah publikasi ilmiah.

Belajar tentang Pendidikan Kewarganegaraan (PKn) pada dasarnya adalah belajar tentang keindonesiaan, belajar untuk menjadi manusia yang berkepribadian Indonesia, membangun rasa kebangsaan, dan mencintai tanah air Indonesia. Oleh karena itu, seorang sarjana atau profesional sebagai bagian dari stakeholder Indonesia yang terdidik perlu memahami tentang Indonesia, memiliki kepribadian Indonesia, memiliki rasa kebangsaan Indonesia, dan mencintai tanah air Indonesia. Dengan demikian, ia menjadi warga negara yang baik dan terdidik 
(smart and good citizen) dalam kehidupan stakeholder, bangsa, dan negara yang demokratis.

Tujuan pendidikan kewarganegaraan di mana pun umumnya bertujuan untuk membentuk warga negara yang baik (good citizen). Kita dapat mencermati Undang-Undang RI No. 20 Tahun 2003 tentang Sisdiknas Pasal 37 Ayat (1) huruf b yang menyatakan bahwa kurikulum pendidikan dasar dan menengah wajib memuat pendidikan kewarganegaraan. Demikian pula pada ayat (2) huruf b dinyatakan bahwa kurikulum pendidikan tinggi wajib memuat pendidikan kewarganegaraan. Bahkan dalam UU No. 12 Tahun 2012 tentang Pendidikan Tinggi lebih eksplisit dan tegas dengan menyatakan nama mata kuliah kewarganegaraan sebagai mata kuliah wajib. Dikatakan bahwa mata kuliah kewarganegaraan adalah pendidikan yang mencakup Pancasila, Undang- Undang Dasar Negara Republik Indonesia Tahun 1945, Negara Kesatuan Republik Indonesia dan Bhinneka Tunggal Ika untuk membentuk mahasiswa menjadi warga negara yang memiliki rasa kebangsaan dan cinta tanah air.

Secara konseptual, istilah kewarganegaraan tidak bisa dilepaskan dengan istilah warga negara. Selanjutnya ia juga berkaitan dengan istilah pendidikan kewarganegaraan. Dalam literatur Inggris ketiganya dinyatakan dengan istilah citizen, citizenship dan citizenship education. Hubungan dari ketiga istilah tersebut, dikemukakan oleh John J. Cogan, \& Ray Derricott dalam buku Citizenship for the 21st Century: An International Perspective on Education (1998), berikut ini: A citizen was defined as a 'constituent member of society'. Citizenship on the other hand, was said to be a set of characteristics of being a citizen'. And finally, citizenship education the underlying focal point of a study, was defined as 'the contribution of education to the development of those charateristics of a citizen'. Selanjutnya secara yuridis, istilah kewarganegaraan dan pendidikan kewarganegaraan di Indonesia dapat ditelusuri dalam peraturan perundangan berikut ini yaitu Kewarganegaraan adalah segala hal ihwal yang berhubungan dengan warga negara. (Undang-Undang RI No.12 Tahun 2006 Pasal 1 Ayat 2) Pendidikan kewarganegaraan dimaksudkan untuk membentuk peserta didik menjadi manusia

Secara yuridis, Pendidikan Kewarganegaraan dimaksudkan untuk membentuk peserta didik menjadi manusia yang memiliki rasa kebangsaan dan cinta tanah air. Secara terminologis, pendidikan kewarganegaraan adalah program pendidikan yang berintikan demokrasi politik, diperluas dengan sumber-sumber pengetahuan lainnya: pengaruh-pengaruh positif dari pendidikan sekolah, stakeholder, dan orang tua. Kesemuanya itu diproses guna melatih para siswa untuk berpikir kritis, analitis, bersikap dan bertindak demokratis dalam mempersiapkan hidup demokratis berdasarkan Pancasila dan UUD 1945. Negara perlu menyelenggarakan pendidikan kewarganegaraan karena setiap generasi adalah orang baru yang harus mendapat pengetahuan, sikap/nilai dan keterampilan agar mampu mengembangkan warga negara yang memiliki watak atau karakter yang baik dan cerdas (smart and good citizen) untuk hidup dalam kehidupan berstakeholder, berbangsa dan bernegara sesuai dengan demokrasi konstitusional. PKn Indonesia lahir karena tuntutan konstitusi atau UUD 1945 dan sejumlah kebijakan Pemerintah yang berkuasa sesuai dengan masanya. Pendidikan Kewarganegaraan senantiasa menghadapi dinamika perubahan dalam sistem ketatanegaraan dan pemerintahan serta tantangan kehidupan berbangsa dan bernegara. PKn Indonesia untuk masa depan sangat ditentukan oleh pandangan bangsa Indonesia, eksistensi konstitusi negara, dan tuntutan dinamika perkembangan bangsa 


\section{Kesimpulan}

Untuk mencapai kompetensi professional mata kuliah PKn, pokok pokok dan isi materi bahan ajar yang dikembangkan mencakup Hakikat Pendidikan PKn , Esensi dan Urgensi Identitas Nasional, Urgensi Integrasi Nasional, Nilai dan Norma Konstitusional UUD NRI 1945 dan Perundang-Undangan di Bawah UUD, Harmoni Kewajiban dan Hak Negara dan Warga Negara, Hakikat, Instrumentasi, dan Praksis Demokrasi Indonesia Berlandaskan Pancasila dan UUD NRI 1945, Dinamika Historis Konstitusional, Sosial-Politik, Kultural, serta Penegakan Hukum yang Berkeadilan,. Dinamika Historis, dan Urgensi Wawasan Nusantara, Urgensi dan Tantangan Ketahanan Nasional dan Bela Negara Bagi Indonesia.

\section{Saran}

Agar kompetensi lulusan tercapai, disamping diperlukannya isi materi bahan ajar yang sesuai para dosen pengampu mata kuliah perlu menerapkan strategi perkuliahan dengan model dan metode perkuliahan yang menyenangkan dan menantang secara bervariasi seperti ceramah bervariasi, presentasi dan diskusi, simulasi, dan pemberian tugas baik secara individu maupun kelompok. Media perkuliahan yang digunakan yaitu dengan laptop, LCD, software berisi pointer / hand out materi perkuliahan yang berbasiskan TPACK. Jenis Penilaian mencakup kehadiran dan partisipasi mahasiswa dalam perkuliahan penugasan kepada mahasiswa berupa membuat chapter report dari referensi nasional tentang semangat kebangsaan (tugas kelompok), mengadakan kunjungan studi ke tempat yang sarat dengan nilai sejarah dan patriotisme, ujian Tengah Semester (UTS) serta ujian Akhir Semester (UAS)

\section{Referensi}

BNSP, 2006. Panduan Penyusunan Kurikulum Tingkat Satuan Pendidikan jenjang Tingkat Pendidikan Dasar dan Menengah. Jakarta: Badan Standar Nasional Pendidikan.

Cogan, J dan Derricot, R. 1998. Citizenship for The 21st Century International Perspective on Education. London: Kogan Page

Peraturan Presiden no. 8 tahun 2012 tentang KKNI

Undang-undang Republik Indonesia $\quad$ No.20 Tahun 2003 tentang Sistem Pendidikan Nasional

Undang-Undang Dasar Negara Republik Indonesia Tahun 1945 (Amandemen).

Undang- undang No 3 tahun 2002 tentang Pertahanan Negara.

Undang-undang Republik Indonesia Nomor 12 Tahun 2012 tentang Pendidikan Tinggi

Undang-undang Republik Indonesia No 3 Tahun 2002 tentang Pertahanan Negara

Undang-undang Republik Indonesia No 14 Tahun 2005 tentang Guru dan Dosen

Undang-Undang Republik Indonesia No.12 Tahun 2006 tentang Kewarganegaraan Indonesia. 